\title{
Inability to stimulate skeletal muscle or whole body protein synthesis in Type 1 (insulin-dependent) diabetic patients by insulin-plus-glucose during amino acid infusion: studies of incorporation and turnover of tracer $L-\left[1-{ }^{13} \mathrm{C}\right]$ leucine
}

\author{
W. M.Bennet ${ }^{1,2}$, A.A.Connacher ${ }^{1,2}$, K. Smith ${ }^{1}$, R.T.Jung ${ }^{2}$ and M. J.Rennie ${ }^{1}$ \\ Departments of ${ }^{1}$ Anatomy and Physiology and ${ }^{2}$ Medicine, University of Dundee, Dundee, Scotland, UK
}

\begin{abstract}
Summary. Despite its anabolic effects on protein balance, acute administration of insulin has been reported to have no effect on skeletal muscle or whole body protein synthesis in man. However, insulin also reduces plasma and intramuscular amino acid availability, which may limit protein synthesis. We have therefore measured the acute effects of insulin on skeletal muscle (anterior tibialis) protein synthesis and whole body leucine turnover in eight insulin-withdrawn Type 1 (insulin-dependent) diabetic patients. They were studied initially when insulin deficient, but during infusion of mixed amino acids at a rate sufficient to raise plasma amino acids by $30 \%$ i.e. to $4 \mathrm{mmol} / \mathrm{l}$ in total; measurements were continued when insulin was infused together with an increased rate of amino acids to maintain insulinopoenic plasma amino acid concentrations. Using ${ }^{13} \mathrm{C}-\alpha$-ketoisocaproate in plasma as an index of the intracellular precursor labelling, incorporation of $\left[1{ }^{-13} \mathrm{C}\right]$ leucine into skeletal muscle protein was $0.068 \pm 0.007 \% / \mathrm{h}$ during insulin withdrawal and was un-
\end{abstract}

altered during insulin infusion. The value is higher than observed in muscle of healthy man, possibly because of a stimulatory effect of endogenous intramuscular amino acids. Also, calculated on the basis of $\alpha$-ketoisocaproate labelling, nonoxidised whole body leucine disappearance (i. e. whole body protein synthesis) was $110 \pm 4 \mu \mathrm{mol} \cdot \mathrm{kg}^{-1} \cdot \mathrm{h}^{-1}$ during insulin withdrawal; this also was unchanged during insulin infusion. Despite stable or increased plasma concentrations of most amino acids, the intramuscular concentrations of a number of amino acids decreased during insulin infusion. This may have limited any anabolic effect of insulin on protein synthesis. Alternatively, pre-existing high intramuscular amino acids may have maximally stimulated muscle protein synthesis, so that the further elevation was obscured, especially with the tendency to depletion of precursor amino acids.

Key words: Protein turnover, insulin, amino acids, muscle, Type 1 (insulin-dependent) diabetes mellitus.
Insulin has a protein anabolic effect in mammals. Insulin deficiency in immature streptozotocin-diabetic rats depresses skeletal muscle protein synthesis, both in vitro and in vivo, which is corrected by replacement of insulin [1-4]. However insulin stimulation of protein synthesis is difficult to reproduce in non-diabetic postabsorptive adult rats [5] and lambs [6]. Muscle protein synthesis in postabsorptive insulin-deficient Type 1 (insulin-dependent) diabetic patients is reported as neither below that in healthy subjects nor responsive to insulin [7]. Furthermore, although close arterial infusion of insulin (which caused no systemic fall in plasma amino acids) increased the net protein balance of the forearm in postabsorptive healthy men [8], local protein synthesis was unaffected; the anabolism appeared to be entirely the effect of insulin in reducing forearm protein breakdown.

Studies in man suggest that the availability of amino acids, which is reduced by insulin in plasma [9-11] and in muscle [11], is a major factor modulating rates of whole body $[9,10,12]$ and muscle $[12,13]$ protein synthesis. Other factors which reduce (3-hydroxybutyrate [14] or increase (e.g. glucagon $[15,16]$ ) amino acid oxidation may indirectly regulate protein synthesis by changing amino acid availability. Infusion of insulin plus glucose, together with amino acids sufficient to maintain plasma concentrations, had noeffect on whole body protein synthesis but appeared to reduce whole body protein breakdown $[9,10]$ thereby improving protein balance; these results raise doubts about any physiologically important role in man for insulin in controlling whole body protein synthesis. Nevertheless, hyperaminoacidaemia during hyperinsulinaemia was accompanied by a rise in whole body protein synthesis [10].

In extrapolating from these results to muscle, caution needs to be exercised: if insulin stimulation of human protein synthesis occurred principally in skeletal muscle this might only be disclosed by direct measurement of muscle protein synthesis, which accounts for $30-50 \%$ of the whole body value $[12,17]$; such a demonstration might also require that insulin-induced muscle amino acid deficiency, by inhibition of protein breakdown, did not constrain 
muscle protein synthesis. The present work was undertaken to investigate the acute effects of insulin infusion on skeletal muscle protein synthesis in Type 1 diabetic subjects under conditions in which any constraint on protein synthesis from insufficient amino acid availability was minimized by continuous infusion of a proprietary mixed amino acid solution at a rate which was increased during the insulin administration.

\section{Subjects and methods}

\section{Subjects}

We studied eight Type 1 diabetic male patients, in good health and free of major diabetic complications despite diabetes for $14 \pm 3$ years; biochemical tests indicated good diabetic control $\left(\mathrm{HbA}_{1} 8.6 \pm 0.7 \%\right.$, normal $\left.<8.5 \%\right)$ and normal renal, hepatic and thyroid function. Five were completely, and three partially, deficient in C-peptide $(0.13,0.21$ and $0.43 \mathrm{nmol} / \mathrm{I}$ during hyperglycaemia and ketosis); their total daily insulin was $52 \pm 6 \mathrm{IU}$. Three additional agematched subjects were studied without tracer to check for effects of the metabolic interventions on baseline ${ }^{13} \mathrm{CO}_{2}$ enrichments. After a full explanation, all subjects gave informed consent for the study, which was approved by the Tayside Health Board ethical committee.

\section{Materials}

$\mathrm{L}-\left[1-{ }^{13} \mathrm{C}\right]$ Leucine and sodium $\left[{ }^{13} \mathrm{C}\right]$ bicarbonate (both $99 \%{ }^{13} \mathrm{C}$ ) were purchased from Tracer Technologies Inc. (Somerville, Mass, USA). Synthamin 14 mixed amino acid solution was obtained from Baxter Healthcare (Egham, UK). Potato-starch glucose (with a low ${ }^{13} \mathrm{C}$ abundance [18]) was obtained from Tunnel Refineries Ltd. (Greenwich, UK) and was prepared for infusion.

\section{Protocol}

Each subject was studied over $240 \mathrm{~min}$ after overnight insulin withdrawal and then for a further 240 min during insulin and glucose infusion. During the period prior to the study all subjects were prescribed high-fibre diets in which carbohydrate supplied over $50 \%$ and fat $30-40 \%$ of total energy. They were given half of their usual dose of short-acting insulin, with no intermediate or long-acting insulin, at 18.00 hours prior to the study day; they then fasted until the end of the study.

At 09.00 hours a cannula was inserted retrogradely into a dorsal hand vein, and maintained patent by slow infusion of $150 \mathrm{mmol} / \mathrm{l}$ $\mathrm{NaCl}$; the hand was inserted into a thermostatically controlled chamber $\left(75^{\circ} \mathrm{C}\right)$ for $15 \mathrm{~min}$ prior to collection of arterialized venous blood samples [19]. Priming doses of $\mathrm{L}-\left[1-{ }^{13} \mathrm{C}\right]$ leucine $(6.84 \pm 0.25 \mu \mathrm{mol} / \mathrm{kg})$ and sodium $\left[{ }^{13} \mathrm{C}\right]$ bicarbonate $(2.83 \pm 0.33$ $\mu \mathrm{mol} / \mathrm{kg}$ ) were then administered (time $0 \mathrm{~min}$ ) and a continuous infusion of L- $\left[1-{ }^{13} \mathrm{C}\right]$ leucine $\left(7.59 \pm 0.32 \mu \mathrm{mol} \cdot \mathrm{kg}^{-1} \cdot \mathrm{h}^{-1}\right)$ commenced via a contralateral forearm vein cannula. At the same time a priming dose of Synthamin 14 mixed amino acid solution ( $29 \mu \mathrm{mol}$ leucine $/ \mathrm{kg}$, $52 \mathrm{mg}$ amino acids $/ \mathrm{kg}$ ) was given over $10 \mathrm{~min}$; Synthamin 14 was then continuously infused at a rate providing leucine $25 \mu \mathrm{mol} \cdot \mathrm{kg}^{-1} \cdot \mathrm{h}^{-1}$ until the end of the period of insulin withdrawal (time $270 \mathrm{~min}$ ). A priming dose [20] of Humulin S neutral human insulin (Eli Lilly and Co. Ltd., Basingstoke, UK) was then given followed by a continuous infusion at $40 \mathrm{mU} \cdot \mathrm{m}^{-2} \cdot \mathrm{min}^{-1}$ and the rate of Synthamin 14 was increased to provide leucine at $93 \mu \mathrm{mol} \cdot \mathrm{kg}^{-1} \cdot \mathrm{h}^{-1}$ until time $510 \mathrm{~min}$. Glucose was infused when the plasma glucose concentration fell to $5 \mathrm{mmol} / \mathrm{l}$.

Thirty min after priming with $\mathrm{L}-\left[1-{ }^{13} \mathrm{C}\right]$ leucine and beginning the mixed amino acid infusion (i. e. elapsed time $30 \mathrm{~min}$ ), a percutaneous muscle biopsy was obtained from the tibialis anterior [21] at a depth of $10 \mathrm{~mm}$ below the fascia using $6.5 \mathrm{~mm}$ Tilley Henckel ethmoid punches (S. Murray and Co, Sheffield, UK), via a $10 \mathrm{~mm}$ long skin incision made $2-4 \mathrm{~min}$ after $5 \mathrm{ml}$ of lignocaine $2 \%$ s.c. A second muscle biopsy was taken from the same or the contralateral leg 240 min later at the end of the insulin withdrawal period, and a third biopsy from the leg contralateral to that first biopsied at time $510 \mathrm{~min}$, the end of the insulin infusion period. The muscle samples were immediately frozen, and stored in, liquid nitrogen until analysis.

Blood samples were obtained before tracer administration, at the time of the first muscle biopsy ( $30 \mathrm{~min}$ ), and every $60 \mathrm{~min}$ thereafter. Coincident samples of expired air were collected into evacuated $20 \mathrm{ml}$ glass tubes (Vacutainer, Becton Dickinson, NJ, USA) for subsequent determination of ${ }^{13} \mathrm{CO}_{2}$ enrichment. Total carbon dioxide production (by infrared analysis) and oxygen consumption (by paramagnetic analysis) were determined for 11 min every 60 min with a ventilated-hood indirect calorimeter, as previously described [22]. Energy expenditure was calculated from Weir's formula [23].

In all subjects we avoided interference with the estimation of $\left[{ }^{13} \mathrm{C}\right]$ leucine oxidation from oxidation of maize-derived dextrose, which has a high natural abundance of ${ }^{13} \mathrm{C}\left(-9.85\left(\delta^{13} \mathrm{C}_{\mathrm{PDB}} \% \mathrm{o}\right)\right)$, by the use of potato starch glucose, which does not $\left(-20.180\left(\delta^{13} \mathrm{C}_{\mathrm{PDB}} \%\right)\right)[18]$. In the three control subjects who did not receive ${ }^{13} \mathrm{C}$ tracer, breath samples were obtained to measure possible background changes, including the effects of increased amino acid oxidation, in the ${ }^{13} \mathrm{C}$ enrichment of expired $\mathrm{CO}_{2}$.

\section{${ }^{13}$ Canalysis}

Plasma $\alpha$-ketoisocaproate, plasma leucine and intramuscular free leucine ${ }^{13} \mathrm{C}$ enrichments were measured by gas chromatography mass spectrometry as described previously [12]; plasma $\alpha$ ketoisocaproate concentrations were determined using $\alpha$-ketovalerate as internal standard. The true intramuscular free leucine enrichment was calculated from that measured on the basis that the sample contained both intracellular and extracellular fluid in the assumed ratio of 13:87 [24]. An isotope ratio mass spectrometer was used to determine both expired $\mathrm{CO}_{2}{ }^{13} \mathrm{C}$ enrichment [25] and protein bound leucine ${ }^{13} \mathrm{C}$ enrichment in ninhydrin-cleaved carboxyl- $\mathrm{CO}_{2}$ [26] of leucine, purified by preparative-gas chromatography [27], from acid-hydrolysed muscle protein [12].

\section{Metabolite and hormone concentration assays}

An automated analyser (LC5000, Biotronic GmbH, Munich, FRG) was used to measure concentrations of amino acids from plasma and intramuscular water [12], the latter calculated on the assumption that $13 \%$ of the muscle biopsy water was extracellular [27]. Plasma glucose was determined with a Glucose Analyzer 2 (Beckman Instruments, Irvine, Calif, USA). At 210, 270, 450 and $510 \mathrm{~min}$ blood D-(-)-3-hydroxybutyrate concentration was measured by an NADlinked enzyme assay [28], and plasma free insulin, glucagon, cortisol and insulin-like growth factor 1 were assayed using commercial radioimmunoassay kits [12]: free insulin was polyethylene glycol separated at the bedside [29] before assay and insulin-like growth factor 1 was measured with a double antibody kit from Nicols Institute Diagnostics (San Juan Capistrano, Calif, USA). C-peptide concentration, measured only once, initially, was determined with a double antibody kit (Ire-Medgenix Sa, Brussels, Belgium).

\section{Mixed amino acid infusion}

Each litre of Synthamin 14 contained the following L-amino acids: alanine $17.6 \mathrm{~g}$, arginine $9.78 \mathrm{~g}$, glycine $8.76 \mathrm{~g}$, histidine $4.08 \mathrm{~g}$, isoleucine $5.10 \mathrm{~g}$, leucine $6.20 \mathrm{~g}$, lysine $4.93 \mathrm{~g}$, methionine $3.40 \mathrm{~g}$, phenylalanine $4.76 \mathrm{~g}$, proline $5.78 \mathrm{~g}$, serine $4.25 \mathrm{~g}$, threonine $3.57 \mathrm{~g}$, tryptophan $1.53 \mathrm{~g}$, tyrosine $0.34 \mathrm{~g}$, valine $4.93 \mathrm{~g}$, total amino acids $85.0 \mathrm{~g}$. 
Table 1. Effect of insulin on plasma hormone, glucose and blood D-(-)-3-hydroxybutyrate concentrations

\begin{tabular}{|c|c|c|}
\hline & $\begin{array}{l}\text { Insulin } \\
\text { withdrawn } \\
210-270 \mathrm{~min}\end{array}$ & $\begin{array}{l}\text { Insulin } \\
\text { infused } \\
450-510 \mathrm{~min}\end{array}$ \\
\hline Free insulin (mU/l) & $4.6 \quad(2.0,10.5)$ & $62.6(56.2,69.6)^{\mathrm{b}}$ \\
\hline Glucagon (pmol/l) & $53 \quad(30,95)$ & $69 \quad(47,100)$ \\
\hline Cortisol (nmol/l) & $300 \quad(145,624)$ & $306 \quad(170,548)$ \\
\hline $\begin{array}{l}\text { Insulin-like growth } \\
\text { factor } 1(\mathrm{mU} / \mathrm{ml})\end{array}$ & $560 \quad(330,970)$ & $500 \quad(320,790)$ \\
\hline Glucose $(\mathrm{mmol} / \mathrm{l})$ & $12.3 \pm 2.0$ & $6.2 \pm 0.9^{a}$ \\
\hline $\begin{array}{l}\mathrm{D}(-) 3 \text {-hydroxybutyrate } \\
(\mathrm{mmol} / \mathrm{l})\end{array}$ & $0.53(0.16,1.74)$ & $0.09(0.03-0.29)^{2}$ \\
\hline
\end{tabular}

Data given as means, with $95 \%$ confidence limits in parenthesis ${ }^{\mathrm{a}} p<0.01,{ }^{\mathrm{b}} p<0.001$

\section{Calculations}

The average rate of mixed skeletal muscle protein synthesis $\left(k_{\mathrm{s}}\right)$ during the 240 min periods between biopsies was calculated as:

$k_{s}(\% / h)=\left(\Delta E_{m} \times 100\right) /\left(E_{1} \times \Delta t\right)$

where $\Delta \mathrm{E}_{\mathrm{m}}=$ increase in protein bound leucine enrichment between biopsies and $E_{p}=$ mean plasma $\alpha$-ketoisocaproate enrichment during the elapsed period $(\Delta t)$ between biopsies [12]. Whole body leucine oxidation was calculated from the mean ${ }^{23} \mathrm{Cenrichment}$ of plasma $\alpha$-ketoisocaproate (the immmediate precursor of leucine oxidation), the mean ${ }^{13} \mathrm{C}$ enrichment of expired $\mathrm{CO}_{2}$ (assuming a bicarbonate recovery fraction of 0.81 ) and the total $\mathrm{CO}_{2}$ production rate during the periods $90-270 \mathrm{~min}$ and $330-510 \mathrm{~min}$ [30]. Plasma $\alpha-$ ketoisocaproate ${ }^{13} \mathrm{C}$ enrichment was used to calculate whole body leucine rates of appearance $(\mathrm{Ra})$ and of disappearance $(\mathrm{Rd})$ with non-steady state equations [31]; the whole body leucine pool size was calculated from the sum of plasma leucine and $\alpha$-ketoisocaproate concentrations and a distribution volume of $0.6 \mathrm{l} / \mathrm{kg}$ body weight assuming that plasma leucine concentration reflects that within tissue cells during both amino acid infusion [12] and during insulin infusion [11]. If a distribution volume of $0.125 \mathrm{l} / \mathrm{kg}$ was used the actual values obtained were different but there were no important relative differences (results not shown) and we have adopted the larger volume as likely to be more physiological. Endogenous leucine appearance (i. e. whole body protein breakdown) was calculated by subtracting the infusion rate of Synthamin 14 leucine from $\mathrm{Ra}$, and non-oxidised leucine disappearance (i.e. whole body protein synthesis) was calculated by subtracting leucine oxidation from $\mathrm{Rd}$. Mean leucine kinetics over the periods $90-270 \mathrm{~min}$ and $330-510 \mathrm{~min}$ were used as the basis of assessment of the effects of insulin and glucose upon whole body protein turnover. Plasma $\alpha$-ketoisocaproate ${ }^{13} \mathrm{C}$ enrichment was taken as the most reliable index upon which to calculate $[12,32$, 33] whole body leucine kinetics and muscle $\mathrm{k}_{\mathrm{s}}$. Nevertheless, we have calculated muscle synthesis using intracellular leucine labelling and whole body turnover using plasma leucine labelling, and the resulting data are presented where appropriate.

\section{Statistical analysis}

Mean \pm SEM values are presented; for D-(-)-3-hydroxybutyrate and hormones, which showed log-normal distributions, the values were transformed to their natural logarithms before analysis; the means and $95 \%$ confidence intervals presented are the antilog transforma- $_{\mathrm{e}}$ tions. Significance of differences for each phase of the study were compared by Student's two-tailed $t$-test for paired data. A value of $p$ $<0.05$ was considered significant. A stepwise regression analysis (Microstat, Ecosoft Inc, Indianapolis, Ind, USA) was performed to compare changes in the rates of skeletal muscle protein synthesis with changes in blood D-(-)-3-hydroxybutyrate concentration and respiratory quotient and with the rate of glucose infusion.
Table 2. Plasma amino acid concentrations $(\mu \mathrm{mol} / \mathrm{l})$ before and during amino acid (AA) infusion, during insulin withdrawal and during insulin infusion

\begin{tabular}{lccc}
\hline Amino acid & $\begin{array}{c}\text { Before AA } \\
\text { infusion } \\
-15 \mathrm{~min}\end{array}$ & $\begin{array}{l}\text { Insulin } \\
\text { withdrawn } \\
30-270 \mathrm{~min}\end{array}$ & $\begin{array}{l}\text { Insulin } \\
\text { infused } \\
330-510 \mathrm{~min}\end{array}$ \\
\hline Alanine & $266 \pm 24$ & $423 \pm 92^{\mathrm{c}}$ & $791 \pm 190^{\mathrm{d}}$ \\
Arginine & $133 \pm 21$ & $203 \pm 26^{\mathrm{d}}$ & $304 \pm 39^{\mathrm{d}}$ \\
Asparagine & $44 \pm 3$ & $47 \pm 3^{\mathrm{b}}$ & $29 \pm 2^{\mathrm{d}}$ \\
Glutamic acid & $61 \pm 8$ & $60 \pm 25$ & $48 \pm 23^{\mathrm{c}}$ \\
Glutamine & $632 \pm 45$ & $695 \pm 140^{\mathrm{c}}$ & $612 \pm 94^{\mathrm{b}}$ \\
Glycine & $229 \pm 23$ & $369 \pm 40^{\mathrm{d}}$ & $588 \pm 59^{\mathrm{d}}$ \\
Histidine & $99 \pm 5$ & $141 \pm 8^{\mathrm{d}}$ & $200 \pm 15^{\mathrm{d}}$ \\
Isoleucine & $110 \pm 15$ & $183 \pm 19^{\mathrm{d}}$ & $274 \pm 25^{\mathrm{d}}$ \\
Leucine & $211 \pm 24$ & $333 \pm 32^{\mathrm{d}}$ & $407 \pm 39^{\mathrm{c}}$ \\
Lysine & $202 \pm 12$ & $257 \pm 18^{\mathrm{c}}$ & $328 \pm 32^{\mathrm{b}}$ \\
Methionine & $27 \pm 2$ & $52 \pm 6^{\mathrm{d}}$ & $103 \pm 12^{\mathrm{d}}$ \\
Phenylalanine & $64 \pm 2$ & $96 \pm 4^{\mathrm{d}}$ & $161 \pm 7^{\mathrm{d}}$ \\
Serine & $131 \pm 17$ & $191 \pm 28^{\mathrm{c}}$ & $251 \pm 34^{\mathrm{d}}$ \\
Taurine & $66 \pm 6$ & $64 \pm 5$ & $47 \pm 3^{\mathrm{d}}$ \\
Threonine & $145 \pm 18$ & $198 \pm 28^{\mathrm{c}}$ & $247 \pm 37$ \\
Tryptophan & $48 \pm 4$ & $60 \pm 3$ & $96 \pm 6^{\mathrm{d}}$ \\
Tyrosine & $57 \pm 3$ & $54 \pm 4^{\mathrm{a}}$ & $41 \pm 3^{\mathrm{d}}$ \\
Valine & $320 \pm 32$ & $431 \pm 37^{\mathrm{d}}$ & $588 \pm 60^{\mathrm{c}}$ \\
Total amino acids & $2950 \pm 150$ & $4000 \pm 240^{\mathrm{d}}$ & $5120 \pm 350^{\mathrm{d}}$ \\
\hline
\end{tabular}

Comparisons are $30-270 \mathrm{~min}$ vs $-15 \mathrm{~min}$ and $330-510 \mathrm{~min}$ vs $30-270 \mathrm{~min} ;{ }^{\mathrm{a}} p<0.05, \quad{ }^{\mathrm{b}} p<0.02, \quad{ }^{\circ} p<0.01, \quad{ }^{\mathrm{d}} p<0.001$; values are means \pm SEM

\section{Results}

\section{Indirect calorimetry}

During insulin whithdrawal carbon dioxide production was $204 \pm 7 \mathrm{ml} / \mathrm{min}$ and increased by $11 \%$ during insulin infusion $(p<0.01)$; respiratory quotient was $0.72 \pm 0.01$ and increased to $0.75 \pm 0.01(p<0.01)$; calculated heat production was $5.69 \pm 0.26 \mathrm{~kJ} / \mathrm{min}$ and increased by $5 \%$ to $6.00 \pm 0.26 \mathrm{~kJ} / \mathrm{min}$ during insulin replacement $(p<0.01)$.

\section{Hormone and substrate concentrations (Table 1)}

Blood bicarbonate before infusion was $23.1 \pm 0.5 \mu \mathrm{mol} / 1$ and remained in the range 22-25 throughout. Plasma hormone concentrations were stable within each phase of the study. During insulin infusion, plasma free insulin concentration increased from low $(4.6 \mathrm{mU} / \mathrm{l})$ to high physiological values $(62.6 \mathrm{mU} / \mathrm{l})$. Plasma glucagon, cortisol and insulin-like growth factor 1 were unchanged. Plasma glucose and blood D-(-)-3-hydroxybutyrate were stable during insulin withdrawal and decreased during insulin infusion. During the final $60 \mathrm{~min}$ of insulin infusion the rate of glucose infusion was $2.17 \pm 0.64 \mathrm{mg} \cdot \mathrm{kg}^{-1} \cdot \mathrm{min}^{-1}$.

\section{Amino and keto acid concentrations (Tables 2 and 3)}

Mean plasma leucine concentration (Fig.1) was $211 \pm 24 \mu \mathrm{mol} / 1$ before the start of the primed amino acid infusion. The plasma leucine concentration increased by $13 \%$ throughout the period when leucine kinetics were calculated during insulin withdrawal $(p<0.02)$; mean plasma leucine was $337 \pm 33 \mu \mathrm{mol} / 1$ during this period. The plasma leucine concentration decreased by $18 \%$ throughout the period when leucine kinetics were calcu- 
Table 3. Effect of insulin on intramuscular free amino acid concentrations $(\mu \mathrm{mol} / 1)$ during amino acid infusion

\begin{tabular}{lccc}
\hline Amino acid & \multicolumn{2}{c}{ Insulin withdrawn } & $\begin{array}{c}\text { Insulin } \\
\text { infused }\end{array}$ \\
\cline { 2 - 3 } & $30 \mathrm{~min}$ & $270 \mathrm{~min}$ & $510 \mathrm{~min}$ \\
\hline Alanine & $1920 \pm 140$ & $2090 \pm 180$ & $3340 \pm 160^{\mathrm{d}}$ \\
Arginine & $608 \pm 104$ & $598 \pm 112$ & $607 \pm 113$ \\
Asparagine & $897 \pm 44$ & $914 \pm 71$ & $850 \pm 67$ \\
Glutamic acid & $4750 \pm 300$ & $4820 \pm 460$ & $3050 \pm 210^{\mathrm{c}}$ \\
Glutamine & $13400 \pm 800$ & $13200 \pm 1900$ & $11600 \pm 900^{\mathrm{a}}$ \\
Glycine & $1510 \pm 100$ & $1570 \pm 90$ & $1640 \pm 110$ \\
Histidine & $597 \pm 72$ & $652 \pm 95$ & $562 \pm 85^{\mathrm{a}}$ \\
Isoleucine & $149 \pm 17$ & $175 \pm 31$ & $173 \pm 33$ \\
Leucine & $298 \pm 32$ & $341 \pm 9$ & $282 \pm 50^{\mathrm{c}}$ \\
Lysine & $1808 \pm 257$ & $2214 \pm 286$ & $1376 \pm 344$ \\
Phenylalanine & $95 \pm 8$ & $105 \pm 8$ & $145 \pm 9^{d}$ \\
Serine & $690 \pm 75$ & $670 \pm 86$ & $650 \pm 84$ \\
Taurine & $17600 \pm 900$ & $17700 \pm 1300$ & $16100 \pm 1100$ \\
Threonine & $769 \pm 56$ & $729 \pm 68$ & $705 \pm 68$ \\
Tyrosine & $89 \pm 6$ & $81 \pm 4^{\mathrm{b}}$ & $21 \pm 7^{\mathrm{d}}$ \\
Valine & $448 \pm 79$ & $444 \pm 79$ & $492 \pm 100$ \\
Total amino acids & $45200 \pm 1300$ & $45000 \pm 2100$ & $41200 \pm 170^{\mathrm{a}}$ \\
\hline Comparisons are & $30 \mathrm{~min}$ &
\end{tabular}

Comparisons are $30 \mathrm{~min}$ vs $270 \mathrm{~min}$ and $270 \mathrm{~min}$ vs $510 \mathrm{~min}$ ${ }^{\mathrm{a}} p<0.05,{ }^{\mathrm{b}} p<0.02,{ }^{c} p<0.01,{ }^{\mathrm{d}} p<0.001$; values given are means \pm SEM

Table 4. Enrichments (Atoms \% excess, APE) of plasma and intramuscular free leucine and $\alpha$-ketoisocaproate, and their ratios, during $\left[1-{ }^{13} \mathrm{C}\right]$ leucine infusion .

\begin{tabular}{lll}
\hline & $\begin{array}{l}\text { Insulin } \\
\text { withdrawn } \\
90-270 \mathrm{~min}\end{array}$ & $\begin{array}{l}\text { Insulin } \\
\text { infused } \\
330-510 \mathrm{~min}\end{array}$ \\
\hline Plasma leucine (APE) & $5.01 \pm 0.21$ & $4.19 \pm 0.18^{\mathrm{b}}$ \\
Plasma $\alpha$-ketoisocaproate (APE) & $4.70 \pm 0.31$ & $4.19 \pm 0.23^{\mathrm{a}}$ \\
$\begin{array}{l}\text { Intramuscular leucine (APE) } \\
\text { Plasma } \alpha \text {-ketoisocaproate/plasma }\end{array}$ & $3.82 \pm 0.27^{\mathrm{c}}$ & $3.33 \pm 0.32^{\mathrm{c}}$ \\
$\begin{array}{l}\text { leucine } \\
\text { Intramuscular leucine/plasma }\end{array}$ & $0.94 \pm 0.05$ & $0.99 \pm 0.03$ \\
$\begin{array}{l}\text { leucine } \\
\text { Intramuscular leucine/plasma }\end{array}$ & $0.76 \pm 0.04$ & $0.80 \pm 0.07$ \\
$\alpha$-ketoisocaproate & $0.82 \pm 0.05$ & $0.80 \pm 0.06$ \\
\hline
\end{tabular}

Comparisons are $330-510$ vs $90-270 \min ^{a} p<0.02 ;{ }^{b} p<0.001$;

c Intramuscular leucine enrichment was significantly different $(p<0.02)$ from plasma leucine and plasma $\alpha$-ketoisocaproate at 90-270 and 330-510 min; ' Intramuscular leucine was measured at $270 \mathrm{~min}$ and $510 \mathrm{~min}$

lated during insulin infusion ( $p<0.01$ ); the mean concentration during this period $(407 \pm 39 \mu \mathrm{mol} / \mathrm{l})$ was $21 \%$ higher than during insulin withdrawal $(p<0.01)$. Plasma $\alpha$-ketoisocaproate concentration was $53 \pm 9 \mu \mathrm{mol} / \mathrm{l}$ during insulin withdrawal and was not significantly different during insulin infusion $(43 \pm 7 \mu \mathrm{mol} / \mathrm{l})$. The total concentration and concentrations of most individual amino acids in plasma (Table 2) were increased by the amino acid infusion given at a faster rate during insulin administration. Exceptions were asparagine, glutamic acid, glutamine, tyrosine (Fig. 1) and taurine which all decreased. The concentration of free leucine in intramuscular water (Fig.1, Table 3) was not different from the plasma concentration before insulin, i. e. at 30 or at $270 \mathrm{~min}$. During insulin infusion the intramuscular leucine concentration decreased
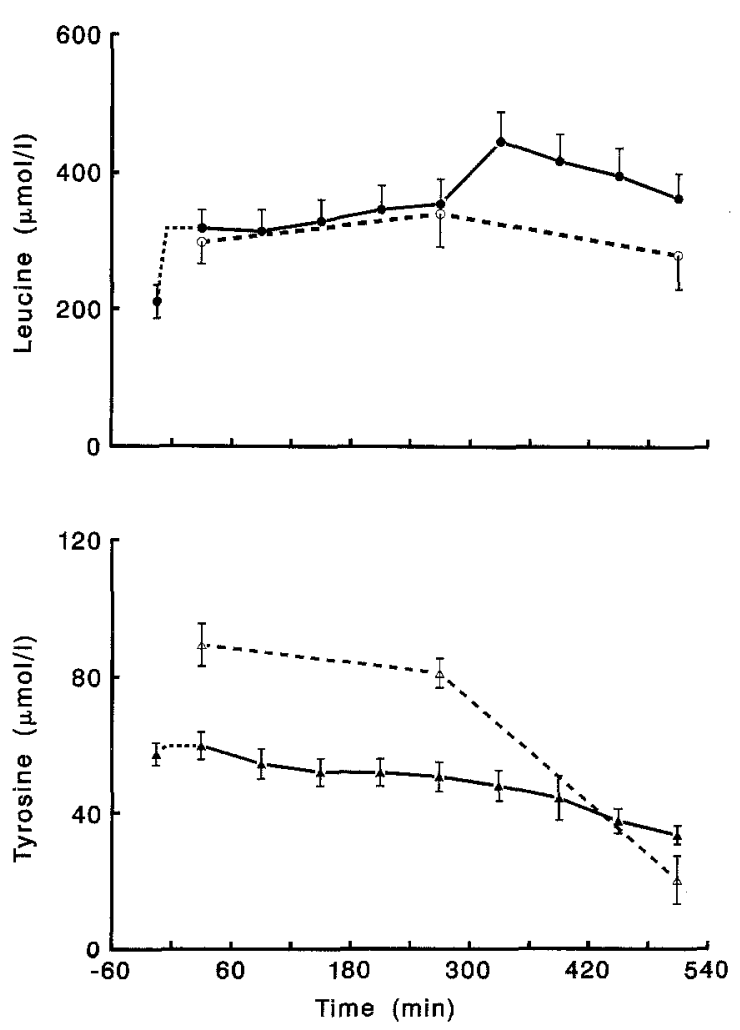

Fig. 1. Upper panel: plasma (- - ) and intramuscular (-O-) leucine concentrations were not different during insulin withdrawal but the intramuscular leucine was lower $(p<0.01)$ during insulin infusion. Lower panel: plasma $\left(-\mathbf{A}_{-}\right)$and intramuscular $\left(-\Delta_{-}\right)$tyrosine concentrations decreased ( $p<0.001$ in each case) to low levels during insulin infusion; values are means \pm SEM

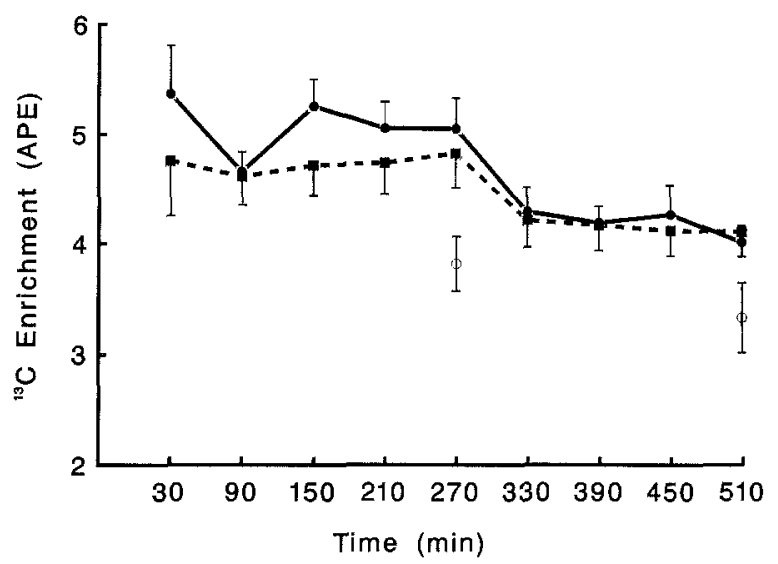

Fig. 2. Plateaux of plasma $\alpha$-ketoisocaproate (-n-) and leucine (-) ${ }^{13} \mathrm{C}$ enrichment (Atoms \% excess, APE) were observed during each phase of study. Intramuscular leucine enrichment $(O)$ did not change; values are means \pm SEM

(when sampled at the end, i.e. at $510 \mathrm{~min}$ ) and was actually lower than both the plasma value at the same time $(p<0.01)$ and the preceding intramuscular value $(p<0.01)$. Despite the general increase in plasma amino acid concentrations when insulin plus additional amino acids were infused a reduction was found in the concentration of total amino acids in intramuscular water. The biggest change occurred for tyrosine which decreased from 


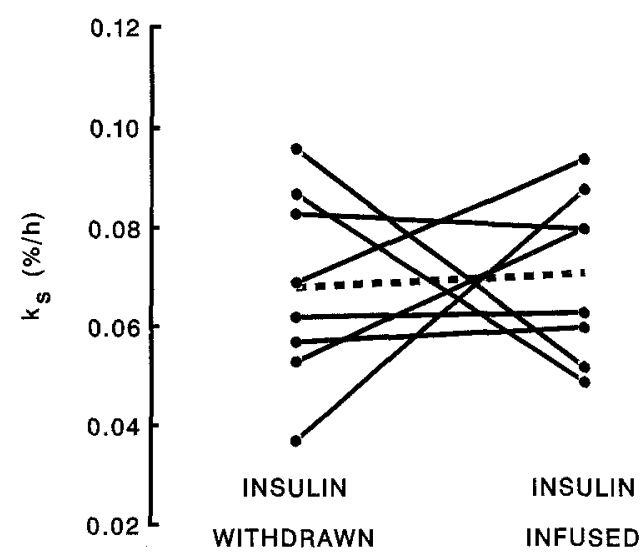

Fig. 3. Mean skeletal muscle protein synthesis rate did not change during insulin infusion; individual (-) and mean values (----) are shown

$81 \pm 4 \mu \mathrm{mol} / \mathrm{l}$ to a mean of only $21 \pm 7 \mu \mathrm{mol} / \mathrm{l}$; it was reduced below detectable values in three subjects (Fig.1).

\section{Enrichment of possible precursors for muscle protein synthesis (Table 4)}

For both plasma $\alpha$-ketoisocaproate and for plasma leucine plateaux of ${ }^{13} \mathrm{C}$ enrichment were observed during insulin withdrawal and significantly reduced plateaux were found during insulin replacement (Table 4, Fig.2). However, leucine enrichment in muscle was unchanged. No differences occurred in the ratios of enrichment of free leucine and its metabolite in plasma or muscle or between them as a result of insulin administration.

Table 5. Anterior tibialis muscle protein synthetic rates $\left(\mathrm{k}_{\mathrm{s}}, \% / \mathrm{h}\right)$ calculated on the basis of enrichment of various possible precursors

\begin{tabular}{lll}
\hline $\begin{array}{l}\text { Possible } \\
\text { precursor }\end{array}$ & $\begin{array}{l}\text { Insulin } \\
\text { withdrawn }\end{array}$ & $\begin{array}{l}\text { Insulin } \\
\text { infused }\end{array}$ \\
\hline Plasma leucine & $0.063 \pm 0.007$ & $0.071 \pm 0.007$ \\
Plasma $\alpha$-ketoisocaproate & $0.068 \pm 0.007$ & $0.071 \pm 0.006$ \\
Intramuscular leucine & $0.084 \pm 0.010^{\mathrm{a}}$ & $0.091 \pm 0.007^{\mathrm{a}}$ \\
\hline
\end{tabular}

${ }^{a} p<0.05$ at least in comparison with plasma leucine or $\alpha$-ketoisocaproate based synthetic rates

Table 6. Effect of insulin on leucine kinetics during amino acid infusion

\begin{tabular}{lll}
\hline & $\begin{array}{l}\text { Insulin } \\
\text { withdrawal } \\
\left(\mu \mathrm{mol} \cdot \mathrm{kg}^{-1} \cdot \mathrm{h}^{-1}\right)\end{array}$ & $\begin{array}{l}\text { Insulin } \\
\text { infusion } \\
\left(\mu \mathrm{mol} \cdot \mathrm{kg}^{-1} \cdot \mathrm{h}^{-1}\right)\end{array}$ \\
\hline $\begin{array}{l}\text { Total flux } \\
\text { Infusion }\end{array}$ & $150 \pm 5$ & $176 \pm 5^{\mathrm{a}}$ \\
$\begin{array}{l}\text { Breakdown } \\
\text { (endogenous Ra) }\end{array}$ & 25 & 93 \\
Total Rd & $125 \pm 5$ & $83 \pm 5^{\mathrm{b}}$ \\
Synthesis (Non-Ox Rd) & $110 \pm 4$ & $185 \pm 4^{\mathrm{b}}$ \\
Oxidation & $35 \pm 3$ & $117 \pm 4$ \\
\hline a $p<0.01,{ }^{\mathrm{b}} p<0.001 ;$ values given are means $\pm \mathrm{SEM} ; \mathrm{Ra}=$ rate of \\
appearance and $\mathrm{Rd}=$ rate of disappearance
\end{tabular}
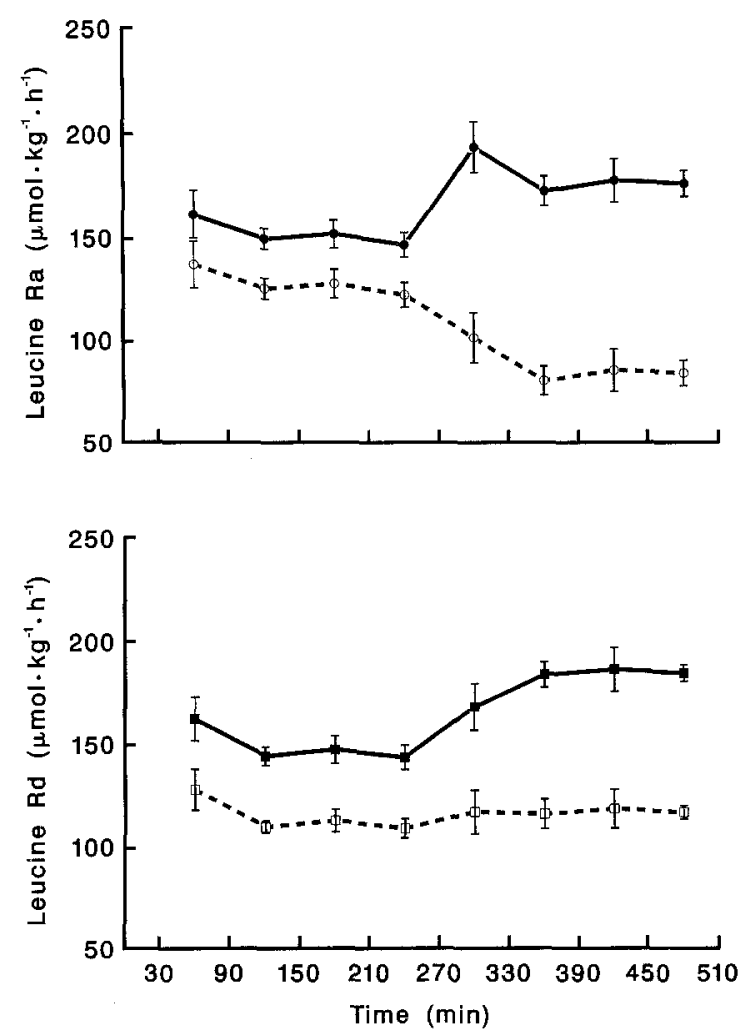

Fig.4. Upper panel: whole body total leucine appearance (- - ) increased $(p<0.01)$, on account of the increased rate of exogenous infusion, and endogenous leucine appearance ( $\left.-\mathrm{O}_{-}-\right)$decreased $(p<0.01)$ during insulin infusion. Lower panel: total leucine disappearance $(-\mathbf{-}-)$ increased $(p<0.01)$, due to increased leucine oxidation $(p<0.001)$, and leucine disappearance to protein $(-\square--)$ was unchanged. $\mathrm{Ra}=$ rate of appearance; $\mathrm{Rd}=$ rate of disappearance

\section{Skeletal muscle mixed protein synthesis}

Mixed skeletal muscle protein synthesis $\left(\mathrm{k}_{\mathrm{s}}\right)$ was $0.068 \pm 0.007 \% / \mathrm{h}$ during insulin withdrawal (Fig. 3 ) and was unchanged $(0.071 \pm 0.006 \% / \mathrm{h})$ during insulin replacement. If muscle protein synthesis rates were calculated on the basis of the enrichment of plasma or intracellular leucine (Table 5), they tended to be lower or were higher than on the basis of the plasma $\alpha$-ketoisocaproate labelling, respectively, but no effects of insulin-plus-glucose were seen. From the present $\alpha$-ketoisocaproate based results it can be calculated that there was a $83 \%$ likelihood of detecting an increase of $30 \%$ in skeletal muscle protein synthesis during insulin infusion $(\alpha=0.05$, two-tailed test); thus, the chance of a type II error was only $17 \%$. Individual subjects showed different changes in $\mathrm{k}_{8}$ during insulin infusion but on stepwise regression analysis no correlation was found between the changes in $\mathrm{k}_{\mathrm{s}}$ and changes in the concentration of D-(-)-3-hydroxybutyrate, changes in the respiratory quotient or the absolute glucose infusion rate during hyperinsulinaemia.

\section{Whole body leucine kinetics (Table 6)}

Expired $\mathrm{CO}_{2}{ }^{13} \mathrm{C}$ enrichment was $0.0188 \pm 0.0013$ atoms \% excess (APE) during insulin withdrawal and was higher during insulin infusion $(0.0298 \pm 0.0012 \mathrm{APE}, p<0.001)$. The corresponding mean values were $0.0002 \pm 0.0001$ and 
$0.0009 \pm 0.0005 \mathrm{APE}$ in three subjects not infused with ${ }^{13} \mathrm{C}$ tracer leucine, suggesting that leucine oxidation may have been overestimated by only $3 \%$ during the latter period due to ${ }^{13} \mathrm{CO}_{2}$ released from oxidation of the infused glucose.

Leucine oxidation was $35 \pm 3 \mu \mathrm{mol} \cdot \mathrm{kg}^{-1} \cdot \mathrm{h}^{-1}$ during insulin withdrawal and increased by $84 \%$ during insulin replacement $(p<0.001)$. Whole body leucine turnover was stable during the final $180 \mathrm{~min}$ of each phase of the study. Total leucine appearance (Fig. 4 ) was $150 \pm 5 \mu \mathrm{mol} \mathrm{kg}{ }^{-1}$. $\mathrm{h}^{-1}$ during insulin withdrawal and increased $18 \%$ during insulin replacement $(p<0.01)$; endogenous leucine appearance (protein breakdown) was $125 \pm 5 \mu \mathrm{mol} \cdot \mathrm{kg}^{-1}$. $\mathrm{h}^{-1}$ and decreased by $33 \%(p<0.01)$. On the basis of plasma $\alpha$-ketoisocaproate labelling, total leucine disappearance (Fig.4) was $145 \pm 5 \mu \mathrm{mol} \cdot \mathrm{kg}^{-1} \cdot \mathrm{h}^{-1}$ during insulin withdrawal and increased by $28 \%$ during insulin replacement $(p<0.01)$; the non-oxidised component of Rd (whole body protein synthesis) was $110 \pm 4 \mu \mathrm{mol}$. $\mathrm{kg}^{-1} \cdot \mathrm{h}^{-1}$ and was not significantly different during insulin replacement $\left(117 \pm 4 \mu \mathrm{mol} \cdot \mathrm{kg}^{-1} \cdot \mathrm{h}^{-1}\right)$. However, if the plasma leucine labelling was used instead of $\alpha$-ketoisocaproate and the non-steady equations were applied, then whole body protein synthesis increased from $96.3 \pm 5.4$ to $119.1 \pm 7.1 \mu \mathrm{mol} \cdot \mathrm{kg}^{-1} \cdot \mathrm{h}^{-1}(p<0.01)$. On this basis there was also a reduction in whole body protein breakdown which was highly significant $(p<0.001)$ but it was only by $23 \%$ of the pre-insulin value (results not shown).

\section{Discussion}

In the investigations described here plasma free insulin was increased by insulin infusion from low to high physiological concentrations over $4 \mathrm{~h}$. During insulin infusion, increased infusion of amino acids resulted in indispensable amino acids being maintained at, or slightly above, plasma concentrations seen before insulin. Despite the increased supply of amino acids no significant increase occurred in skeletal muscle protein synthesis during insulin replacement, irrespective of the precursor used as the basis of the calculations.

A number of possibilities might explain this negative result. Although it is possible that in the adult human body the capacity for modulation of muscle protein synthesis by insulin is absent, this seems unlikely, especially in view of the extensive evidence from animal studies [1-4]. Alternatively, insulin may have been ineffective on account of a post-receptor defect of protein metabolism in the diabetic patients (whose glucose metabolism was markedly insulin resistant, as indicated by the low respiratory quotients and glucose disposal rates), but the possible nature of such an effect is presently unknown.

That the rates of anterior tibialis muscle protein synthesis found in the present study during insulin withdrawal tended to be faster ( $p=0.12$ ) than those in seven healthy postabsorptive subjects studied by identical means [12] may offer a further possibility. It seems that at low concentrations of insulin muscle protein synthesis was not pathologically reduced in these diabetic subjects and may even have been elevated, a result in accordance with the results from Halliday's group [7]: thus, skeletal muscle protein synthesis may have been already maximally stimulated in the diabetic patients and a further increase by insulin may not have been possible. This would be in marked contrast to the situation in immature rats in which muscle protein synthesis is reduced at low insulin concentrations [1-4].

There is also the slight possibility that if insulin were initially totally absent, instead of present at very low concentrations (see Table 1), it might have been possible to observe an impairment of basal skeletal muscle protein synthesis in our patients, since in the rat at least, sensitivity of protein synthesis to insulin is already maximal over 0-10 mU/1 [34]. Evidence against this comes from our findings that two subjects in whom insulin was not detectable by our assay had muscle protein synthetic rates comparable with those of the other subjects in whom it was. Nevertheless, this argument cannot be conclusive since the range of insulin sensitivity of protein synthesis in adult man is unknown and may differ markedly from that in young rats and other animals.

The possibility of limitation of intracellular amino acid availability remains to be considered. Amino acid infusion at an increased rate did not prevent an insulin-induced reduction in the muscle water concentration of certain amino acids, most markedly for tyrosine. This reduction may have acted as a constraint on muscle protein synthesis (even though the affinity of tRNA for amino acids is very high in vitro [35]) or the normal stimulatory effect [12] of amino acids on muscle protein synthesis may have been reduced. The amino acid mixture used contained only a small quantity of tyrosine, whose relative insolubility limits its de livery by infusion. Although not indispensable in the whole body in adults, usually being produced in the liver from phenylalanine, it is essential in muscle which cannot synthesize it; the ratio between protein-bound and free tyrosine is high, so that the "safety factor" for tyrosine availability is small [36]. Decreases in the plasma tyrosine may have limited uptake of tyrosine into the limb since its net uptake depends upon the plasma concentrations [37]. Its uptake, by the insulin-independent L-system transporter $[38,39]$, may also have been competitively inhibited by the relatively high concentrations of the branched-chain amino acids, phenylalanine and tryptophan; furthermore, these amino acids may have depleted muscle tyrosine by trans-stimulation [40] of the L-system.

In comparison to healthy postabsorptive subjects [12], the patients with diabetes we studied had markedly raised plasma amino acid concentrations during insulin withdrawal, partly, presumably, as a result of increased protein breakdown as well as amino acid infusion. It seems likely that elevated amino acid availability initially may have contributed to the elevated muscle protein synthetic rates we measured in the insulin withdrawn state, since we have shown previously that muscle protein synthesis in healthy postabsorptive men increased by an average of $35 \%$ during infusion of mixed amino acids alone [12], and we have recently confirmed the effect by arterio-venous tracer amino acid flux measurements in a separate group of subjects [13]. It is difficult to choose which of two possible effects, i.e. stimulation by an initially high intramuscular amino acid concentration or limitation by removal of muscle essential amino acids was most important for the 
lack of a further stimulation by insulin, but both could conceivably have been involved. In any event, our present and previous findings are consistent with the proposition that, in man, availability of amino acids rather than of insulin, is important in maintaining rates of skeletal muscle protein synthesis, and that insulin is less so.

A number of other substrates which could have influenced muscle protein synthesis changed in response to insulin infusion. 3-Hydroxybutyrate apparently stimulates muscle protein synthesis, but by only $10 \%$ as its concentration increases over a fourfold range from $0.5 \mathrm{mmol} / \mathrm{l}[14]$ : we found that insulin caused a small decrease in 3-hydroxybutyrate, making it unlikely that such a change would have relieved a previously stimulatory effect on skeletal muscle protein synthesis. In rat diaphragm and heart muscle in vitro, glucose increases protein synthesis [41] and deficiency of glucose results in increased leucine oxidation [42]. Plasma glucose was elevated during insulin withdrawal but muscle was unlikely to have been able to utilize it efficiently because of lack of insulin and little sparing of amino acid catabolism could have occurred. Other factors not otherwise considered in our patients include elevations of fatty acids and medium-chain triglycerides, the latter being reported to improve forearm balance of amino acids [43].

In addition a number of hormones may have altered in concentration during insulin infusion. Growth hormone (not measured) may have been initially elevated but the patients were in good diabetic control, and plasma insulinlike growth factor 1 was in the normal range making this unlikely. Paracrine and systemic growth factors other than insulin-like growth factor 1 may influence protein synthesis in ways not accessible to our analyses. During insulin infusion plasma free insulin increased into the high physiological range but nevertheless remained beneath the threshold necessary to stimulate insulin-like growth hormone receptors. However, insulin-like growth factor 1 was measured in plasma only and any local muscle cell changes would not have been apparent. We suggest that this is unlikely not only because of a lack of any anabolic effect, but also because increases in insulin-like growth factor 1 normally require considerable exposure to insulin [44].

Marked changes in the rates of muscle protein synthesis were evident between patients; increases occurred in three, but in two patients there were decreases. Stepwise regression analysis showed these changes to correlate with neither indices of insulin sensitivity nor changes in the plasma 3-hydroxybutyrate. Although it is not possible with the present study design to identify specific factors which induced increases in protein synthesis in particular individuals during insulin infusion, the occurrence of the increases suggests that there may have been some stimulation of protein synthesis by a combination of insulin and some unidentified factor.

The muscle biopsy technique used, although invasive, enables measurement of muscle protein synthesis with few inherent assumptions. The plasma enrichment of $\alpha$-ketoisocaproate during infusion of leucine tracer is assumed to represent the labelling of leucyl-tRNA within cells: we have recently obtained good evidence that for pig muscle, with and without infusion of amino acids, it comes closer to the leucyl-tRNA than do a number of other possible indices such as plasma or intracellular leucine [44]. Only circumstantial evidence concerning this question is currently available in man, but it is consistent with our approach [12, $33,34]$. Given the present study conditions, in which plasma leucine concentration was high throughout both phases of investigation, tracer exchange between plasma and the intracellular fluid was likely to be rapid; certainly, we observed ratios of the enrichment of plasma $\alpha$-ketoisocaproate/leucine, intramuscular leucine/plasma leucine and intramuscular leucine/ $\alpha$-ketoisocaproate much closer to unity in the diabetic patients than in healthy subjects studied without infusion of amino acid [12]. There is, therefore, less variation in the magnitudes of rates of muscle protein synthesis in the diabetic patients than in healthy subjects [12] when different precursor pools are used to calculate the muscle protein synthesis rate.

The rates of whole body protein leucine kinetics are in agreement with values published by other workers [4648]. The apparent lack of stimulation by insulin of whole body protein synthesis in the diabetic patients is consistent with results from healthy subjects showing that rates of protein synthesis correlated only with plasma leucine $[9$, 10]. In the present study the observed lack of insulin stimulation of skeletal muscle is consistent with a lack of change in whole body protein synthesis. That leucine oxidation increased with insulin infusion is also in agreement with previous work in which plasma leucine was maintained during insulin infusion [9]. Although insulin deficiency increases leucine oxidation in perfused hind-limbs, from fasted or fed rats, its replacement reduces leucine oxidation in the fed preparation but markedly increases it in the fasted preparation [49]. Also, insulin has been shown to increases leucine oxidation in adipose tissue in vitro [50]. It appears likely that the increased leucine oxidation we observed during insulin infusion occurred in muscle and adipose tissue. The extent of leucine oxidation in different human tissues in vivo is not well documented although the distribution of the $\alpha$-keto acid dehydrogenase [51] suggests muscle to be a major site, and our own arterio-venous measurements suggest that it must be the major one in healthy man $[13,52]$.

The measurement of muscle protein synthesis uses fewer uncheckable assumptions than the assessment of whole body protein synthesis with the tracer dilution technique. In addition to uncertainties of precursor pool labelling [12], changes in insulin action result in alterations of plasma and intramuscular leucine concentration with the result that whole body protein synthesis, calculated with steady state equations, tends to be overestimated duringinsulin withdrawal with the opposite effect during insulin replacement. Although not independently validated the equations that we used take account of the changing tracer concentrations. A further source of error which may have caused underestimation of protein synthesis during the present study conditions is recycling of tracer, which may lead to increased plasma tracer enrichment and underestimation of both flux and protein synthesis despite coincident underestimation of leucine oxidation; however, this is usually only a problem in more prolonged infusions [53]. In the present investigations a bicarbonate recovery value of 
0.81 was used, derived from i. v. tracer-bicarbonate infusion in healthy postabsorptive subjects. As determined from the appearance of tracer-carbon labelling in glucose by incorporation of the carbons during gluconeogenesis, the proportion of bicarbonate fixed during infusions of leucine tracer from oxidation of leucine carboxyl-carbon within mitochondria is greater than occurs during infusion of bicarbonate for the same degree of plasma bicarbonate labelling. Therefore, general use of a bicarbonate recovery value of 0.81 may lead to additional underestimation of leucine oxidation and thus, overestimation of protein synthesis. During provision of glucose, whichstimulatesinsulin secretion and inhibits gluconeogenesis, fixation of tracer-carbon from bicarbonate by gluconeogenesis is reduced [54] and under these conditions the figure of 0.81 may markedly overestimate leucine oxidation exacerbating the underestimation of protein synthesis. Changes also occur in the whole body bicarbonate pool during insulin withdrawal and insulin replacement inducing additional errors in estimates of bicarbonate fixation and leucine oxidation. We probably avoided one source of error in glucose infusion: if maize-derived glucose had been infused, ${ }^{13} \mathrm{CO}_{2}$ released from maize glucose oxidation would have led to an overestimation of leucine oxidation and a further corresponding underestimation of whole body protein synthesis during hyperinsulinaemia. Such factors collectively result in underestimation of whole body protein synthesis by the [1${ }^{13}$ C]leucine dilution technique during hyperinsulinaemic conditions and may induce qualitative errors in the interpretation of the effects of insulin action on whole body protein synthesis, both in our work and that of others $[9,10,46]$.

Comparison of the present whole body leucine metabolism results with those from studies in non-diabetic men, in which whole body protein synthesis was not stimulated by insulin $[9,10]$, are consistent with a lack of any fundamental difference in sensitivity of amino acid metabolism to insulin between diabetic and non-diabetic subjects [47]. Similar conclusions might be drawn by comparing the skeletal muscle leucine incorporation results reported here for Type 1 diabetic subjects with the reported lack of effect of insulin on forearm arterio-venous uptake of phenylalanine in healthy man [8]; however, the different methods used in the two investigations, and the differences in the subjects studied may make comparisons invalid.

Toconclude, in the present study we could not show any acute anabolic effect of systemic insulin infusion on skeletal muscle protein synthesis in insulin-withdrawn adult diabetic patients. It appears possible that reduced intracellular concentrations for a number of amino acids during insulin infusion, in particular tyrosine, may have constrained muscle protein synthesis. The hypothesis that such a deficiency of amino acids, particularly tyrosine, is the reason why protein synthesis is not stimulated by insulin needs to be further investigated using amino acid mixtures including tyrosine dipeptides [55] to increase its availability.

In the meantime the likelihood that increased total amino acid availability maintains muscle protein synthesis in diabetic subjects and that acute treatment with insulin does not stimulate it further must weaken the perception that the general anabolic effect of insulin includes stimulation of muscle protein synthesis. It may be, however, that in normal healthy subjects or in diabetic patients with physiological amino acid concentrations, insulin does stimulate muscle protein synthesis, if sufficient substrate is supplied; the fact that Type 1 diabetic children may grow normally suggests that this is so. We must now design appropriate investigations to test these ideas.

Acknowledgements. We are grateful to Dr. C.M. Scrimgeour and Mr. B. Weryk for their technical skills, and Mrs. D. Watt for secretarial assistance. This study was generously supported by grants from the British Diabetic Association, Eli Lilly and Co. Ltd, the Scottish Home and Health Department, the Scottish Hospitals Endowment Research Trust, Tenovus Tayside, The Rank Prize Funds, The Wellcome Trust and the University of Dundee.

\section{References}

1. Flaim KE, Copenhaver ME, Jefferson LS (1980) Effects of diabetes on protein synthesis in fast- and slow-twitch rat skeletal muscle. Am J Physiol 239: E88-E95

2. Jefferson LS (1980) Role of insulin in the regulation of protein synthesis. Diabetes 29: 487-496

3. Pain VM, Albertse EC, Garlick PJ (1983) Protein metabolism in skeletal muscle, diaphragm, and heart of diabetic rats. Am J Physiol 245: E604-E610

4. Pain VM, Garlick PJ (1974) Effect of streptozotocin diabetes and insulin treatment on the rate of protein synthesis in tissues of the rat in vivo. J Biol Chem 249: 4510-4514

5. Garlick PJ, McNurlan MA, McHardy KC (1988) Factors controlling the disposition of primary nutrients. Proc Nutr Soc 47 : 169-176

6. Oddy VH, Lindsay DB, Barker PJ, Northop AJ (1987) Effect of insulin on hind-limb and whole-body leucine and protein metabolism in fed and fasted lambs. Br J Nutr 58: 437-452

7. Pacy PJ, Nair KS, Ford C, Halliday D (1989) Failure of insulin to stimulate fractional muscle protein synthesis in Type 1 diabetic patients. Diabetes 38: 618-624

8. Gelfand RA, Barrett EJ (1987) Effect of physiologic hyperinsulinemia on skeletal muscle protein synthesis and breakdown in man. J Clin Invest 80: 1-6

9. Castellino P, Luzi L, Simonson DC, Haymond M, DeFronzo RA (1987) Effect of insulin and plasma amino acid concentrations on leucine metabolism in man: role of substrate availability on estimates of whole body protein synthesis. J Clin Invest 80: 1784-1793

10. Tessari P, Inchiostro S, Biolo G, Trevisan R, Fantin G, Marescotti MC, Iori E, Tiengo A, Crepaldi G (1987) Differential effects of hyperinsulinemia and hyperaminoacidemia on leucine-carbon metabolism in vivo: evidence for distinct mechanisms in regulation of net amino acid deposition. J Clin Invest 79: 1062-1069

11. Alvestrand A, DeFronzo RA, Smith D, Wahren J (1988) Influence of hyperinsulinaemia on intracellular amino acid levels and amino acid exchange across splanchnic and leg tissues in uraemia. Clin Sci 74: 155-163

12. Bennet WM, Connacher AA, Scrimgeour CM, Smith K, Rennie MJ (1989) Increase in anterior tibialis muscle protein synthesis in healthy man during mixed amino acid infusion: studies of incorporation of $\left[1-{ }^{13} \mathrm{C}\right]$ leucine. Clin Sci $76: 447-454$

13. Bennet WM, Connacher AA, Scrimgeour CM, Rennie MJ (1990) The effect of amino acid infusion on leg protein turnover assessed by $\mathrm{L}-\left[{ }^{15} \mathrm{~N}\right]$ phenylalanine and $\mathrm{L}-\left[1-{ }^{13} \mathrm{C}\right]$ leucine exchange. Eur J Clin Invest 20:37-46

14. Nair KS, Welle SL, Halliday D, Campbell RG (1988) Effect of $\beta$-hydroxybutyrate on whole-body leucine kinetics and fractional mixed skeletal muscle protein synthesis in humans. J Clin Invest 82: 198-205

15. Nair KS, Halliday D, Matthews DE, Welle SL (1987) Hyperglucagonemia during insulin deficiency accelerates protein catabolism. Am J Physiol 253: E208-E213 
16. Almdal TP, Vilstrup H (1988) Exogenous hyperglucagonaemia in insulin controlled diabetic rats increases urea excretion and nitrogen loss from organs. Diabetologia 31: 836-841

17. Nair KS, Halliday D, Griggs RC (1988) Leucine incorporation into mixed skeletal protein muscle in humans. Am J Physiol 254: E208-E213

18. Scrimgeour CM, Bennet WM, Connacher AA (1988) A convenient method of screening glucose for ${ }^{13} \mathrm{C}:{ }^{12} \mathrm{C}$ ratio for use in stable isotope tracer studies. Biomed Environ Mass Spectrom 17: 265266

19. Abumrad NN, Rabin D, Diamond MP, Lacy WW (1981) Use of a heated superficial hand vein as an alternative site for the measurement of amino acid concentrations and for the study of glucose and alanine kinetics in man. Metabolism 30:936-940

20. DeFronzo RA, Robin JD, Andres R (1979) Glucose clamp technique: a method for quantifying insulin secretion and resistance. Am J Physiol 237: E214-E223

21. Dietrichson P, Coakley J, Smith PEM, Griffiths RD, Helliwell TR, Edwards RHT (1987) Conchotome and needle percutaneous biopsy of skeletal muscle. J Neurol Neurosurg Psychiatry 50: 1461-1467

22. Illingworth PJ, Jung RT, Howie PW, Leslie P, Isles TE (1986) Diminution of energy expenditure during lactation. Br Med J 292: $437-441$

23. Weir JBD (1949) New methods for calculating metabolic rate with special reference to protein metabolism. J Physiol 109: 1-9

24. Bergström J, Fürst P, Noree L-O, Vinnars E (1974) Intracellular free amino acid concentration in human muscle tissue. J Appl Physiol 36: 693-697

25. Scrimgeour CM, Rennie MJ (1988) Automated measurement of the concentration and ${ }^{13} \mathrm{Cenrichment}$ of carbon dioxide in breath and blood samples using the Finnigan MAT breath gas analysis system. Biomed Environ Mass Spectrom 15: 365-367

26. Scrimgeour CM, Smith K, Rennie MJ (1988) Automated measurement of ${ }^{13} \mathrm{C}$ enrichment in carbon dioxide derived from submicromole quantities of L- $\left(1-{ }^{13} \mathrm{C}\right)$-leucine. Biomed Environ Mass Spectrom 15:369-374

27. Smith K, Scrimgeour CM, Bennet WM, Rennie MJ (1988) Isolation of amino acids by preparative gas chromatography for quantification of carboxyl carbon ${ }^{13} \mathrm{C}$ enrichment by isotope ratio mass spectrometry. Biomed Environ Mass Spectrom 17:267-273

28. Williamson DH, Mellanby J (1974) D-(-)-3-Hydroxybutyrate. In: Bergmeyer HU (ed) Methods of enzymatic analysis. Academic Press, London, pp 1836-1839

29. Rudkowski R, Antony G (1986) The effect of immediate polyethylene glycol precipitation on free insulin measurements in diabetic patients with insulin antibodies. Diabetes 35:253-257

30. Matthews DE, Motil KJ, Rohrbaugh DK, Burke JF, Young VR, Bier DM (1980) Measurement of leucine metabolism in man from a primed, continuous infusion of $\mathrm{L}-\left[1{ }^{-{ }^{13}} \mathrm{C}\right]$ leucine. Am $\mathrm{J}$ Physiol 238: E473-E479

31. Miles JM, Nissen SL, Rizza RA, Gerich JE, Haymond MW (1983) Failure of infused $\beta$-hydroxybutyrate to decrease proteolysis in man. Diabetes 32: 197-205

32. Matthews DE, Schwarz HP, Yang RD, Motil KJ, Young VR, Bier DM (1982) Relationship of plasma leucine and $\alpha$-ketoisocaproate during a $\mathrm{L}-\left[1-{ }^{13} \mathrm{C}\right]$ leucine infusion in man: a method for measuring human intracellular leucine tracer enrichment. Metabolism 31: 1105-1112

33. Schwenk WF, Beaufrere B, Haymond MW (1985) Use of reciprocal pool specific activities to model leucine metabolism in humans. Am J Physiol 249: E646-E650

34. Millward DJ, Bates PC, Brown JG, Rennie MJ (1983) Physiological mechanisms for the regulation of protein balance in skeletal muscle. In: Kidman AD, Tomkins JK, Morris CA, Cooper NA (eds) Molecular pathology of nerve and muscle: noxious agents and genetic lesions. Humana Press, New Jersey, pp 315 342

35. Tyobeka EM, Manchester KL (1985) Control of cell-free protein synthesis by amino acids: effects on tRNA charging. Int J Biochem 17: 873-877
36. Waterlow JC, Garlick PJ, Millward DJ (1978) Protein turnover in mammalian tissues and in the whole body, Elsevier, Amsterdam

37. Lundholm K, Bennegård K, Zachrisson H, Lundgren F, Edén E, Möller-Loswick A-C (1987) Transport kinetics of amino acids across the resting human leg. J Clin Invest 80: 763-771

38. Yudilevich DL, Boyd CAR (1987) Amino acid transport in animal cells. Manchester University Press, Manchester

39. Hundal HS, Rennie MJ, Watt PW (1989) Characteristics of acidic, basic and neutral amino acid transport in perfused rat hindlimb. J Physiol 408: 93-114

40. Stein WD (1986) Transport and diffusion across cell membranes. Academic Press, Orlando

41. Hedden MP, Buse MG (1982) Effects of glucose, pyruvate, lactate and amino acids on muscle protein synthesis. Am J Physiol 242: E184-E192

42. Buse MG, Biggers FJ, Friderici KH, Buse JF (1972) Oxidation of branched chain amino acids by isolated hearts and diaphragms of the heart: the effect of fatty acids, glucose, and pyruvate respiration. J Biol Chem 247: 8085-8096

43. Wicklmayr M, Rett K, Schwiegelshohn B, Wolfram G, Hailer S, Dietze $G$ (1987) Inhibition of muscular amino acid release by lipid infusion in man. Eur J Clin Invest 17: 301-305

44. Watt PW, Stenhouse MG, Corbett ME, Rennie MJ (1989) tRNA charging in pig muscle during fasting and infusion of amino acids. Clin Nutr 8 [Suppl]: 0.73; 47 (Abstract)

45. Glaser EW, Goldstein S, Phillips LS (1987) Nutrition and somatomedin, XVII. Circulating somatomedin C during treatment of diabetic ketoacidosis. Diabetes 36:1152-1160

46. Nair KS, Garrow JS, Ford C, Mahler RF, Halliday D (1983) Effect of poor diabetic control and obesity on whole body protein metabolism in man. Diabetologia 25: 400-403

47. Tessari P, Nosadini R, Trevisan R, De Kreutzenberg SV, Inchiostro S, Duner E, Biolo G, Marescotti C, Tiengo A, Crepaldi G (1986) Defective suppression by insulin of leucine-carbon appearance and oxidation in Type 1 , insulin dependent diabetes mellitus: evidence for insulin resistance involving glucose and amino acid metabolism. J Clin Invest 77: 1797-1804

48. Nair KS, Ford GC, Halliday D (1987) Effect of intravenous insulin treatment on in vivo whole body leucine kinetics and oxygen consumption in insulin-deprived Type 1 diabetic patients. Metabolism 36: 491-495

49. Hutson SM, Zapalowski C, Cree TC, Harper AE (1980) Regulation of leucine and $\alpha$-ketoisocaproic acid metabolism in skeletal muscle. Effects of starvation and insulin. J Biol Chem 255:24182426

50. Frick GP, Goodman HM (1980) Insulin regulation of branched chain $\alpha$-keto acid dehydrogenase in adipose tissue. J Biol Chem 255: 6186-6192

51. Khatra BS, Chawla RK, Sewell CW, Rudman D (1977) Distribution of branched-chain $\alpha$-keto acid dehydrogenases in primate tissues. J Clin Invest 59; 558-564

52. Cheng KN, Dworzak F, Ford GC, Rennie MJ, Halliday D (1985) Direct determination of leucine metabolism and protein breakdown in humans using $\mathrm{L}-\left[1-{ }^{13} \mathrm{C},{ }^{15} \mathrm{~N}\right]$-leucine and the forearm model. Eur J Clin Invest 15: 349-354

53. Schwenk WF, Tsalikian E, Beaufrere B, Haymond M (1985) Recycling of an amino acid label with prolonged isotope infusion: implications for kinetic studies. Am J Physiol 248: E482-E487

54. McMahon M, Marsh H, Rizza R (1989) Comparison of the pattern of postprandial carbohydrate metabolism after ingestion of a glucose drink or a mixed meal. J Clin Endocrinol Metab 68: 647-653

55. Albers S, Wernerman J, Stehle P, Vinnars E, Fürst P (1988) Availability of amino acids supplied intravenously in healthy man as synthetic dipeptides: kinetic evaluation of L-alanyl-L-glutamine and glycyl-L-tyrosine. Clin Sci 75: 463-468

Received: 24 May 1989

and in revised form: 4 September 1989

Prof. M.J.Rennie

Department of Anatomy and Physiology, University of Dundee

Dundee DD1 4HN, Scotland, UK 